\title{
Environmental Processes
}

\section{Constraints on aerosol nitrate photolysis as a potential source of HONO and NO}

Paul Romer, Paul J. Wooldridge, John D. Crounse, Michelle J Kim, Paul O. Wennberg, Jack Dibb, Eric Scheuer, Donald R. Blake, Simone Meinardi, Alexandra L. Brosius, Alexander B. Thames, David O. Miller, William H. Brune, Samuel R. Hall, Thomas B. Ryerson, and Ronald Carl Carl Cohen

Environ. Sci. Technol., Just Accepted Manuscript • DOI: 10.1021/acs.est.8b03861 • Publication Date (Web): 08 Nov 2018

Downloaded from http://pubs.acs.org on November 13, 2018

\section{Just Accepted}

"Just Accepted" manuscripts have been peer-reviewed and accepted for publication. They are posted online prior to technical editing, formatting for publication and author proofing. The American Chemical Society provides "Just Accepted" as a service to the research community to expedite the dissemination of scientific material as soon as possible after acceptance. "Just Accepted" manuscripts appear in full in PDF format accompanied by an HTML abstract. "Just Accepted" manuscripts have been fully peer reviewed, but should not be considered the official version of record. They are citable by the Digital Object Identifier (DOI®). "Just Accepted" is an optional service offered to authors. Therefore, the "Just Accepted" Web site may not include all articles that will be published in the journal. After a manuscript is technically edited and formatted, it will be removed from the "Just Accepted" Web site and published as an ASAP article. Note that technical editing may introduce minor changes to the manuscript text and/or graphics which could affect content, and all legal disclaimers and ethical guidelines that apply to the journal pertain. ACS cannot be held responsible for errors or consequences arising from the use of information contained in these "Just Accepted" manuscripts. 


\section{Constraints on aerosol nitrate photolysis as a potential source of $\mathrm{HONO}$ and $\mathrm{NO}_{x}$}

Paul S. Romer, ${ }^{\dagger}$ Paul J. Wooldridge, ${ }^{\dagger}$ John D. Crounse, ${ }^{\ddagger}$ Michelle J. Kim, ${ }^{\ddagger}$ Paul O.

Wennberg, ${ }^{\ddagger}$, Jack E. Dibb, ${ }^{\S}$ Eric Scheuer, ${ }^{\S}$ Donald R. Blake, Alexandra L. Brosius, ${ }^{\perp}$ Alexander B. Thames, ${ }^{\perp}$ David O. Miller, ${ }^{\perp}$ William $\mathrm{H}$. Brune, ${ }^{\perp}$ Samuel R. Hall, \# Thomas B. Ryerson, ${ }^{\circledR}$ and Ronald C. Cohen ${ }^{*, \dagger}, \triangle$ $\dagger$ Department of Chemistry, University of California Berkeley, Berkeley, CA 94720, USA $\ddagger$ Division of Geological and Planetary Sciences, California Institute of Technology, Pasadena, CA 91125, USA

\Division of Engineering and Applied Science, California Institute of Technology, Pasadena, CA 91125, USA

§Institute for the Study of Earth, Oceans, and Space, University of New Hampshire, Durham, NH 03824, USA

||Department of Chemistry, University of California Irvine, Irvine, CA 92697, USA $\perp$ Department of Meteorology and Atmospheric Science, The Pennsylvania State University, University Park, PA 16802, USA \#Atmospheric Chemistry Observations and Modeling Laboratory, NCAR, Boulder, CO 80301, USA

$@$ Chemical Sciences Division, NOAA Earth System Research Laboratory, Boulder, CO 80305, USA

$\triangle$ Department of Earth and Planetary Sciences, University of California Berkeley, Berkeley, CA 94720, USA

E-mail: rccohen@berkeley.edu 


\begin{abstract}
The concentration of nitrogen oxides $\left(\mathrm{NO}_{\mathrm{x}}\right)$ plays a central role in controlling air quality. On a global scale, the primary sink of $\mathrm{NO}_{\mathrm{x}}$ is oxidation to form $\mathrm{HNO}_{3}$. Gas-phase $\mathrm{HNO}_{3}$ photolyses slowly with a lifetime in the troposphere of 10 days or more. However, several recent studies examining HONO chemistry have proposed that particle-phase $\mathrm{HNO}_{3}$ undergoes photolysis 10-300 times more rapidly than gas-phase $\mathrm{HNO}_{3}$. We present here constraints on the rate of particle-phase $\mathrm{HNO}_{3}$ photolysis based on observations of $\mathrm{NO}_{\mathrm{x}}$ and $\mathrm{HNO}_{3}$ collected over the Yellow Sea during the KORUSAQ study in summer 2016. The fastest proposed photolysis rates are inconsistent with the observed $\mathrm{NO}_{\mathrm{x}}$ to $\mathrm{HNO}_{3}$ ratios. Negligible to moderate enhancements of the $\mathrm{HNO}_{3}$ photolysis rate in particles, 1-30 times faster than in the gas phase, are most consistent with the observations. Small or moderate enhancement of particle-phase $\mathrm{HNO}_{3}$ photolysis would not significantly affect the $\mathrm{HNO}_{3}$ budget, but could help explain observations of $\mathrm{HONO}$ and $\mathrm{NO}_{\mathrm{x}}$ in highly aged air.
\end{abstract}

\title{
Introduction
}

Nitrogen oxides $\left(\mathrm{NO}_{\mathrm{x}} \equiv \mathrm{NO}+\mathrm{NO}_{2}\right)$ are a central component of atmospheric chemistry, affecting air quality, climate, and ecosystem health. The concentration of $\mathrm{NO}_{\mathrm{x}}$ regulates the concentration of major atmospheric oxidants and controls the pathways of atmospheric oxidation. Accurate knowledge of the chemical sources and sinks of $\mathrm{NO}_{\mathrm{x}}$ is therefore vital to understanding atmospheric oxidation and predicting how air quality will respond to changes in anthropogenic emissions or to changes in the global climate system.

On a global scale, the largest sink of $\mathrm{NO}_{\mathrm{x}}$ is oxidation of $\mathrm{NO}_{2}$ by $\mathrm{OH}$ to form $\mathrm{HNO}_{3} \cdot{ }^{1}$ In the lower troposphere, gas-phase $\mathrm{HNO}_{3}$ is removed by wet and dry deposition, with an overall lifetime of only a couple days. Chemical removal of gas-phase $\mathrm{HNO}_{3}$ is much slower, with a lifetime to photolysis or oxidation by $\mathrm{OH}$ of $15-30$ days in the troposphere. ${ }^{2}$ In remote locations, even this slow rate can be relevant and act as an important source of $\mathrm{NO}_{\mathrm{x}}$. 
$\mathrm{HNO}_{3}$ can also partition into aerosols, forming inorganic particle-phase nitrate $\left(\mathrm{NO}_{3}^{-}\right)$. Dry deposition is slow for most particles, but particle-phase nitrate can be lost by wet deposition, or it can be lost by re-partitioning between phases as gas-phase $\mathrm{HNO}_{3}$ is deposited. ${ }^{3}$ Throughout this manuscript, we use $\mathrm{HNO}_{3}$ to refer to the sum of gas-phase nitric acid and inorganic particle-phase nitrate.

Previous studies examining the chemical evolution of $\mathrm{NO}_{\mathrm{x}}$ and $\mathrm{HNO}_{3}$ in the absence of fresh emissions have found varying results. While Bertram et al. ${ }^{4}$ and Neuman et al. ${ }^{5}$ found good agreement between observations and models, several other studies reported elevated concentrations of $\mathrm{NO}_{\mathrm{x}}$ that could not be explained with known chemistry. ${ }^{6-8}$ To reconcile models and observations, multiple pathways for the conversion of $\mathrm{HNO}_{3}$ into $\mathrm{NO}_{\mathrm{x}}$ or $\mathrm{HONO}$ have been proposed, a process termed re-noxification. Various re-noxification pathways have been proposed in areas including the upper troposphere, ${ }^{7-9}$ the marine boundary layer, ${ }^{6,10-12}$ rural forests, ${ }^{13,14}$ and areas of continental outflow. ${ }^{15}$ Recently, several of these studies have suggested that $\mathrm{HNO}_{3}$ is rapidly photolyzed in aerosols to form $\mathrm{NO}_{2}$ or $\mathrm{HONO}$, at a rate between 10 and 300 times faster than the rate of gas-phase $\mathrm{HNO}_{3}$ photolysis, ${ }^{10-12,15,16}$ and it is this process that we investigate here.

Most of the previous studies of this process were primarily focused on the potential for particle-phase nitrate photolysis to explain observations of HONO. To complement the approach of previous studies, we examine the consequences of rapid nitrate photolysis on concentrations of $\mathrm{NO}_{\mathrm{x}}$ and $\mathrm{HNO}_{3}$. Because $\mathrm{HONO}$ is itself rapidly lost by photolysis to produce $\mathrm{NO}$, the effect of nitrate photolysis on $\mathrm{NO}_{\mathrm{x}}$ chemistry does not depend on whether HONO or $\mathrm{NO}_{\mathrm{x}}$ is the direct product. Past studies investigating aerosol nitrate photolysis have reported their results as an enhancement factor $(E F)$, relating the rate of nitric acid photolysis in the particle phase to that in the gas-phase (Eq. 1), and we follow that convention here.

$$
j_{p \mathrm{HNO}_{3}}=E F \cdot j_{g \mathrm{HNO}_{3}}
$$

While mechanistic studies of aerosol nitrate photolysis are limited, investigations of pho- 
tolysis in solution or on surfaces help explain how large enhancements of aerosol-phase nitrate photolysis could be possible. In solution, the cross section of $\mathrm{NO}_{3}{ }^{-}$is enhanced by a factor of 25 at $310 \mathrm{~nm}$ over that of gas-phase $\mathrm{HNO}_{3}$, likely due to symmetry-breaking of the $\mathrm{NO}_{3}{ }^{-}$ ion by hydration. ${ }^{17}$ At the same time, the quantum yield of $\mathrm{NO}_{3}{ }^{-}$photolysis is reduced from near unity in the gas-phase to 0.01 in bulk solution, likely due to recombination of the photolysis products in the solvent cage, leading to an overall slower rate of aqueous-phase nitrate photolysis than that of gas-phase nitric acid. ${ }^{18,19}$

In contrast, nitric acid or nitrate adsorbed on surfaces is not fully enclosed in a solvent cage and is therefore expected to have an enhanced cross section without a significant decrease in the quantum yield. Experimental results have confirmed that the cross section of $\mathrm{HNO}_{3}$ can be enhanced by up to a factor of 1000 at 308-310 nm when adsorbed onto the surface of aluminum or ice. The quantum yield of $\mathrm{HNO}_{3}$ on the same surfaces was 0.60 or greater. ${ }^{20,21}$ Thus, if a significant portion of aerosol nitrate is located on or near the aerosol surface, where its quantum yield remains high, then it is plausible that its photolysis rate could be enhanced multiple orders of magnitude over that of gas-phase nitric acid.

The ratio of $\mathrm{NO}_{\mathrm{x}}$ to $\mathrm{HNO}_{3}$, which we refer to as $R_{\text {obs }}$, provides crucial information about the chemistry of $\mathrm{HNO}_{3} . R_{\text {obs }}$ has been used in past studies to investigate both the production and loss of $\mathrm{HNO}_{3} \cdot{ }^{5-9}$ As a ratio of two concentrations, $R_{\text {obs }}$ is relatively unaffected by the total concentration of reactive nitrogen $\left(\mathrm{NO}_{\mathrm{y}}\right)$ or the total volume of emissions encountered. By eliminating the effects of emissions and dilution, analysis of $R_{\mathrm{obs}}$, rather than absolute $\mathrm{HNO}_{3}$ concentration, helps isolate the effects of $\mathrm{HNO}_{3}$ production and loss and allows comparison of airmasses between different environments.

In this paper, we present new constraints on the rate of particulate nitrate photolysis, based on observations of $\mathrm{NO}_{\mathrm{x}}$ and $\mathrm{HNO}_{3}$ collected onboard the NASA DC-8 aircraft during the KORUS-AQ field campaign. Using $R_{\text {obs }}$ to evaluate $\mathrm{HNO}_{3}$ production and loss, we demonstrate that the fastest proposed nitrate photolysis rates $(E F>30)$ are inconsistent with our current understanding of nitric acid production. Comparisons of the data from 
KORUS-AQ with several other airborne observations show that the results from KORUSAQ are not anomalous, and confirm that particle-phase nitrate photolysis is at most a minor $\mathrm{HNO}_{3}$ loss pathway on a global scale.

\section{Materials and Methods}

\section{Observations}

The primary observations used in this analysis were taken onboard the NASA DC-8 as part of the Korea-United States Air Quality Study (KORUS-AQ) over South Korea during May and June 2016. Crucial observations used in this analysis include $\mathrm{NO}_{\mathbf{x}}$, gas-phase $\mathrm{HNO}_{3}$, particle-phase nitrate, hydroxyl radical $(\mathrm{OH})$, a wide range of volatile organic compounds (VOCs), and the spectrally-resolved actinic flux (used to calculate the gas-phase $\mathrm{HNO}_{3}$ photolysis rate). Throughout the analysis, we use measurements of particle-phase nitrate from bulk aerosols collected onto filters and analyzed by ion chromatography. A full list of species used in this analysis and the techniques used to measure them are listed in Table 1. All analyses were performed using the merged dataset provided by NASA (version 4) of all KORUS-AQ flights, averaged to match the time resolution of the particle-phase nitrate filter measurements.

Additional data were obtained from the NASA LaRC Airborne Science Data for Atmospheric Composition website, from a set of six field deployments on the DC-8: INTEX-NA, MILAGRO, INTEX-B, ARCTAS-B, DC3, and SEAC4RS. A map of all 7 deployments is shown in Fig. S1. All of the campaigns include measurements of $\mathrm{NO}_{\mathrm{x}}, \mathrm{HNO}_{3}$ in the gas and particle phase, $\Sigma \mathrm{RONO}_{2}, \Sigma \mathrm{PANs}$, and VOCs; all but one (SEAC4RS) include measurements of $\mathrm{OH}$, although measurements of OH from INTEX-NA, MILAGRO, and INTEX-B include an interference from internally generated $\mathrm{OH}$ that can be important in some low-altitude environments. ${ }^{22} \mathrm{NO}$ on previous campaigns was always measured by chemiluminescence, but the instrument and group responsible was not consistent. On INTEX-NA, NO was measured 
and loss rates of $\mathrm{NO}_{\mathrm{x}}$ and $\mathrm{HNO}_{3}$ via routes that are not fully constrained from measurements. Secondly, a more comprehensive box model was used to study the evolution of advected plumes over the Yellow Sea. The framework and kinetics used for both applications are described here, while details specific to each application are described in their respective sections.

Simulations were run using the Framework for 0-Dimensional Atmospheric Modeling (F0AM), with chemical kinetics from the Master Chemical Mechanism v3.3.1 (MCM). ${ }^{37,38}$ To include the uncertainty in many of the parameters, multiple simulations were run testing a range of values for each parameter. A full list of parameters specified or added to F0AM and their uncertainty ranges is included in Tables S1-S4 of the supplementary information.

Additional $\mathrm{HNO}_{3}$ sources not included in the MCM were added to the model, including halogen chemistry, alkyl and multifunctional nitrate $\left(\Sigma \mathrm{RONO}_{2}\right)$ hydrolysis, and $\mathrm{N}_{2} \mathrm{O}_{5}$ hydrolysis. Inorganic halogen chemistry was added to the model following the scheme described in Sherwen et al. ${ }^{39}$. Total amounts of reactive chlorine, bromine, and iodine $\left(\mathrm{Cl}_{\mathrm{y}}\right.$, $\mathrm{Br}_{\mathrm{y}}$, and $\mathrm{I}_{\mathrm{y}}$ ) were specified and allowed to partition freely between different halogen species. Total concentrations of $\mathrm{Cl}_{\mathrm{y}}, \mathrm{Br}_{\mathrm{y}}$, and $\mathrm{I}_{\mathrm{y}}$ were set at $18 \mathrm{ppt}, 3.5 \mathrm{ppt}$, and $5.5 \mathrm{ppt}$ respectively, based on the modeled yearly average halogen concentrations over the Yellow Sea by Sherwen et al. ${ }^{39}$.

Multiphase chemistry was added to the model through reactive uptake reactions onto a fixed aerosol surface area concentration. A reactive uptake parameter $(\gamma)$ of 0.005 was applied to all $\mathrm{RONO}_{2}$ with a tertiary nitrate group, equal to that assumed by Fisher et al. ${ }^{40}$ for isoprene hydroxy nitrates. When using observed $\Sigma \mathrm{RONO}_{2}$ concentrations, which are not isomer specific, a $\gamma$ of 0.002 was applied to all nitrates. A $\gamma$ of 0.10 was used for all three $\mathrm{XONO}_{2}$ species, in between the laboratory values for uptake onto aqueous solution (0.03) and uptake onto sulfate aerosol (0.80). ${ }^{41,42}$ A constant $\gamma$ value of 0.014 was included for $\mathrm{N}_{2} \mathrm{O}_{5}$ chemistry. ${ }^{43}$

All the modeling studies were focused on plumes advected over the ocean, and therefore no 
emissions were included in the model. Dilution was included as a first-order decay of model concentrations towards a prescribed background concentration, with an effective dilution rate of $1.7 \times 10^{-5} \mathrm{~s}^{-1}$. The average daytime boundary-layer deposition velocity for gas-phase $\mathrm{HNO}_{3}$ used in the model is $2 \mathrm{~cm} \mathrm{~s}^{-1} \cdot{ }^{44-46}$

\section{Results and Discussions}

\section{$\mathrm{NO}_{\mathrm{x}}$ and $\mathrm{HNO}_{3}$ chemistry during KORUS-AQ}

Boundary layer measurements during KORUS-AQ typically observed high concentrations of $\mathrm{HNO}_{3}$ and $\mathrm{NO}_{\mathrm{x}}$, although there was significant variation in the concentration of both species (Fig. 1). To gain greater sensitivity to the chemical loss processes of $\mathrm{HNO}_{3}$, we restrict our analysis to observations in the boundary layer over the Yellow Sea. The air over the Yellow Sea was highly aged and contained high concentrations of $\mathrm{NO}_{\mathrm{y}}$, averaging $6 \pm 2$ ppb. Together, these properties result in slow chemical production of $\mathrm{HNO}_{3}$ and emphasize the loss processes of $\mathrm{HNO}_{3}$.

Boundary layer observations over the Yellow Sea are shown as the blue bars in Fig. 1. $R_{\text {obs }}$ was typically extremely low, and was significantly lower than the ratios observed in the free troposphere (red bars in Fig. 1), indicating that boundary-layer chemistry, and not dilution, is controlling the ratio. The inorganic components of particles observed over the Yellow Sea were typically dominated by $\mathrm{SO}_{4}{ }^{2-}, \mathrm{NH}_{4}{ }^{+}$, and $\mathrm{NO}_{3}{ }^{-}$(Fig. S2a), although approximately a quarter of the filter samples showed enhanced concentrations of mineral ions (Fig. S2b).

FLEXPART back trajectories initialized from the points sampled by the DC-8 were used to further investigate the origin of the sampled air (Fig. S3) ${ }^{47}$ The airmasses were often stagnant, showing slow circulation over the Yellow Sea, with the occasional rapid transport of air from China. Based on concentrations of $\mathrm{CO}_{2}$ and black carbon, four of the samples appear to be influenced by nearby ship emissions and are excluded from further analysis. 

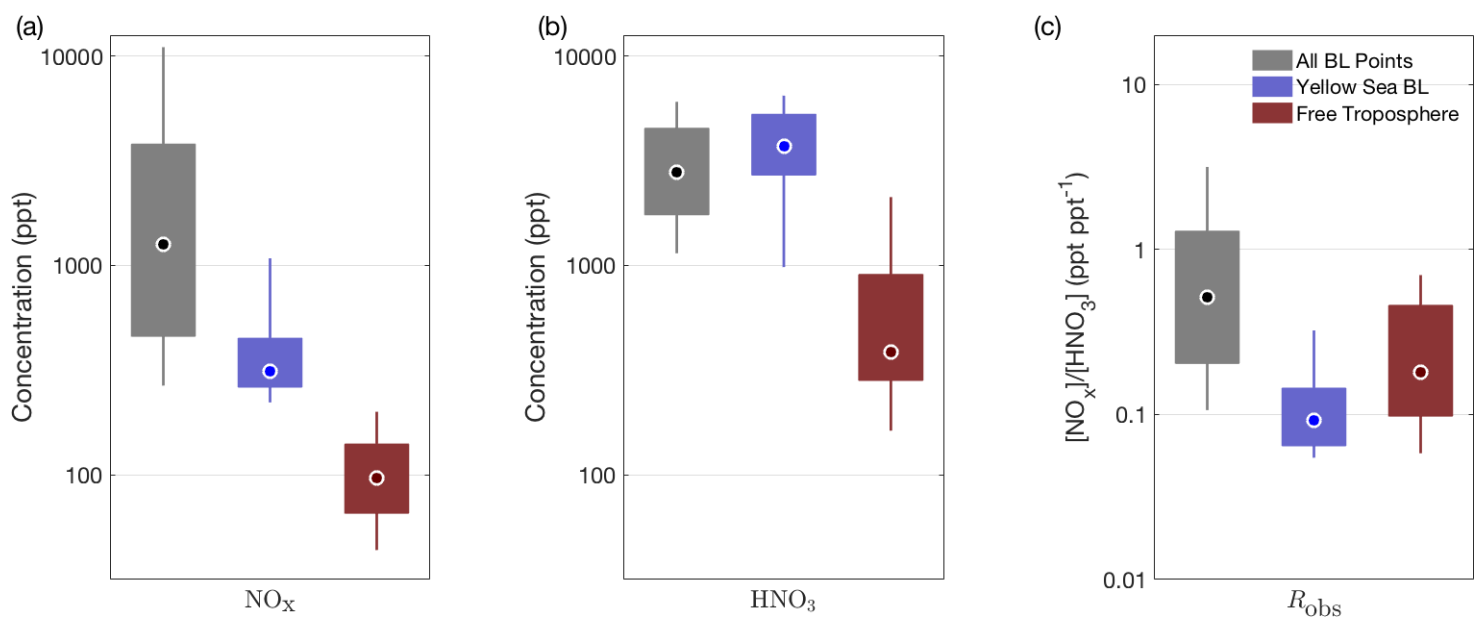

Figure 1: Distribution of $\mathrm{NO}_{\mathrm{x}}, \mathrm{HNO}_{3}$ (gas + particle), and $R_{\text {obs }}$ in three different regions during KORUS-AQ: all points in the boundary layer (gray bars), points in the boundary layer over the Yellow Sea (blue bars) and all points in the lower free troposphere (between 2 and $4 \mathrm{~km}$, red bars). In each bar, the black dot shows the median value, the thick bar the inter-quartile range, and the thin line the $10^{\text {th }}-90^{\text {th }}$ percentiles.

To examine the compatibility of the observations with different proposed $E F$ s, we compare $R_{\text {obs }}$ with the calculated far-field ratios $\left(R_{\mathrm{FF}}\right)$, the predicted ratio of $\mathrm{NO}_{\mathrm{x}}$ to $\mathrm{HNO}_{3}$ in infinitely aged air. Because $\mathrm{HNO}_{3}$ is not directly emitted to the atmosphere but is a product of $\mathrm{NO}_{\mathrm{x}}$ oxidation, in an isolated plume $R_{\mathrm{obs}}$ starts at a maximum value and decreases to approach a far-field ratio set by the relative forward and backward conversion rates between $\mathrm{NO}_{\mathrm{x}}$ and $\mathrm{HNO}_{3}$. This behavior has been seen in past studies of $\mathrm{NO}_{\mathrm{x}}$ chemistry in the outflow of plumes, which have found that $R_{\text {obs }}$ decreases consistently as plumes evolves. ${ }^{4,6,35,48,49}$ None of these studies observed an increase in $R_{\text {obs }}$ with airmass age. Therefore, $R_{\text {obs }}$ is expected to always be greater than or equal to $R_{\mathrm{FF}}$.

Because $R_{\mathrm{FF}}$ represents the predicted $\mathrm{NO}_{\mathrm{x}} / \mathrm{HNO}_{3}$ ratio in infinitely aged air, it is not directly observable. Although air in the free troposphere is typically highly aged, changes in chemistry with altitude prevent the $\mathrm{NO}_{\mathrm{x}} / \mathrm{HNO}_{3}$ ratio in the free troposphere from being a useful proxy for $R_{\mathrm{FF}}$ in the boundary layer. Instead, $R_{\mathrm{FF}}$ is calculated algebraically from the effective first-order chemistry of $\mathrm{NO}_{\mathrm{x}}, \mathrm{HNO}_{3}$, and PAN described by the system of differential equations (2)-(4). The eigenvector of the system with the largest associated eigenvalue gives 
the predicted ratio of $\mathrm{NO}_{\mathrm{x}}$ to $\mathrm{HNO}_{3}$ in infinitely aged air.

$$
\begin{aligned}
\frac{\mathrm{d}\left[\mathrm{NO}_{\mathrm{x}}\right]}{\mathrm{d} t}= & -k_{\text {forward }}\left[\mathrm{NO}_{\mathrm{x}}\right]+k_{\text {backward }}\left[\mathrm{HNO}_{3}\right]-k_{\text {removal }}\left[\mathrm{NO}_{\mathrm{x}}\right] \\
& -k_{\text {assoc }}\left[\mathrm{NO}_{\mathrm{x}}\right]+k_{\text {dissoc }}[\mathrm{PAN}] \\
\frac{\mathrm{d}\left[\mathrm{HNO}_{3}\right]}{\mathrm{d} t}= & k_{\text {forward }}\left[\mathrm{NO}_{\mathrm{x}}\right]-k_{\text {backward }}\left[\mathrm{HNO}_{3}\right]-k_{\text {dep }}\left[\mathrm{HNO}_{3}\right] \\
\frac{\mathrm{d}[\mathrm{PAN}]}{\mathrm{d} t}= & k_{\text {assoc }}\left[\mathrm{NO}_{\mathrm{x}}\right]-k_{\text {dissoc }}[\mathrm{PAN}]
\end{aligned}
$$

The effective rate constants in these equations were calculated using observations from the DC-8, supplemented by box-modeling of unmeasured species. For each observation over the Yellow Sea, an independent box-model simulation was run to calculate the instantaneous concentration of $\mathrm{RO}_{2}$ radicals and halogen nitrates. The partitioning of $\mathrm{HNO}_{3}$ between gas and particle phases was set based on the observed concentrations of gas-phase nitric acid and particle-phase nitrate, and was assumed to remain constant as the plume evolved.

$k_{\text {forward }}$, the effective rate constant for conversion of $\mathrm{NO}_{\mathrm{x}}$ into $\mathrm{HNO}_{3}$, includes the oxidation of $\mathrm{NO}_{2}$ by $\mathrm{OH}$ and the production of $\mathrm{HNO}_{3}$ by $\mathrm{RONO}_{2}, \mathrm{XONO}_{2}$, and $\mathrm{N}_{2} \mathrm{O}_{5}$ hydrolysis. The backwards conversion rate, $k_{\text {backward }}$, includes contributions from gas-phase $\mathrm{HNO}_{3}$ photolysis and oxidation and particle-phase photolysis. The loss of $\mathrm{HNO}_{3}$ by deposition, $k_{\mathrm{dep}}$ was calculated using a deposition rate of $2 \mathrm{~cm} \mathrm{~s}^{-1}$ for gas-phase nitric acid only. $k_{\text {removal }}$ represents the effects of $\mathrm{NO}_{\mathrm{x}}$ removal through oxidation to $\mathrm{RONO}_{2} \cdot k_{\text {assoc }}$ and $k_{\text {dissoc }}$ are the effective first-order rate constants for the formation and dissociation of PAN respectively. Explicit formulas for these six effective first-order rate constants are given by Eq. S1-S6.

Figure 2 shows the ratio of ratios $R_{\mathrm{obs}} / R_{\mathrm{FF}}$ for several different values of the assumed $E F$. In addition to our best-guess estimates, Fig. 2 also shows sensitivity tests using high- and low-end estimates of halogen concentrations and $\mathrm{HNO}_{3}$ deposition velocity, listed in Table $\mathrm{S} 1$. Because observed air masses may not yet have reached far-field conditions, $R_{\mathrm{obs}} / R_{\mathrm{FF}}$ is expected to always be greater than or equal to 1, setting an upper limit on the maximum 


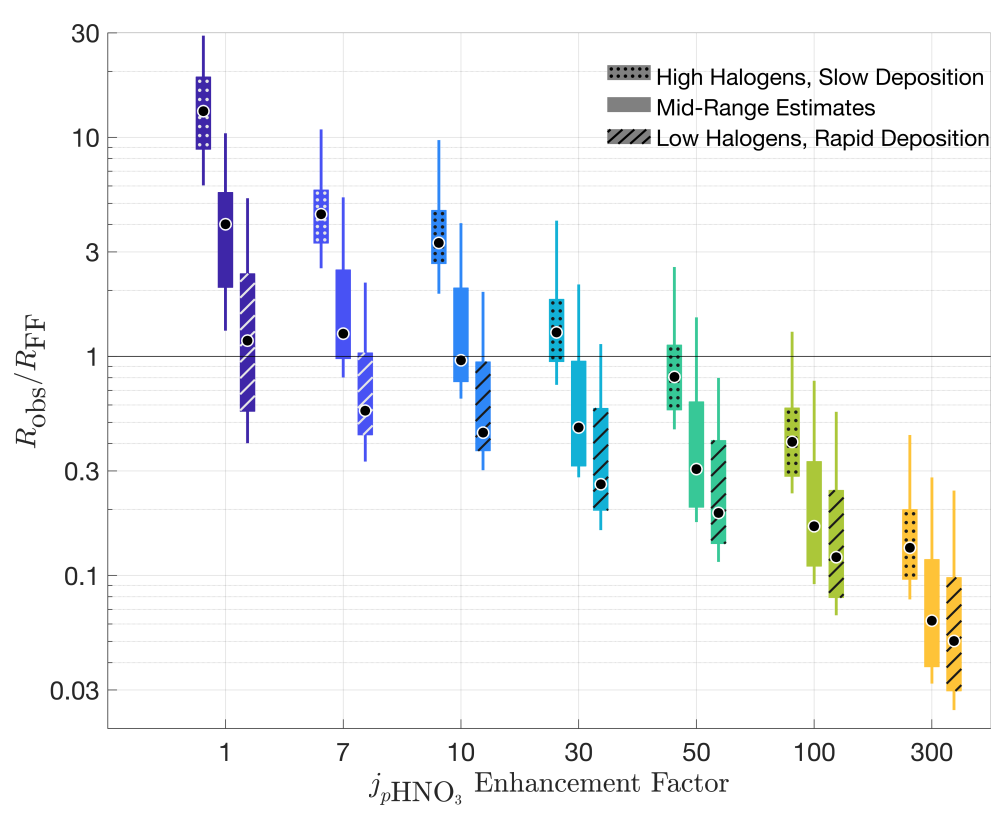

Figure 2: Comparison of $R_{\mathrm{obs}}$ to $R_{\mathrm{FF}}$ in the boundary layer over the Yellow Sea. Each individual bar shows a boxplot of the ratio of ratios, calculated using in-situ data for every observation over the Yellow Sea. For every value of $E F$ tested, $R_{\mathrm{FF}}$ was calculated 3 different ways, using different assumptions for the production of nitric acid via halogen chemistry and the deposition velocity of nitric acid, corresponding to the range of values in Table S1. In each bar, the black dot shows the median value, the thick bar the inter-quartile range, and the thin line the $10^{\text {th }}-90^{\text {th }}$ percentiles. The boxplots are spaced equally and position along the x-axis does not correspond to EF on either a linear or a log scale.

EF compatible with the observations.

Although these values of $R_{\mathrm{FF}}$ are calculated from observations of plumes over the Yellow Sea, they are a reasonable approximation of what would be calculated in infinitely aged air. Fig. S5 in the supporting information shows the measured value of $R_{\text {obs }}$ and the calculated value of $R_{\mathrm{FF}}$ in airmasses of different ages, using all boundary layer observations from KORUS-AQ. While $R_{\text {obs }}$ decreases by 2 orders of magnitude between fresh emissions and highly aged air, $R_{\mathrm{FF}}$ remains roughly constant, further supporting for the conclusion that $R_{\mathrm{obs}} / R_{\mathrm{FF}}$ should never be less than 1 .

Using our best-guess estimates for the unknown parameters, an $E F$ of up to 7 is consistent with the observations. With more generous assumptions, an EF of up to 30 is plausible. However, when an EF of 50 or greater is used, over $75 \%$ of the $R_{\mathrm{FF}}$ 's are greater than the 
observed ratios and are therefore incompatible with the observations. Due to the extremely high values of $R_{\mathrm{obs}} / R_{\mathrm{FF}}$ observed in fresh plumes, the analysis of Fig. 2 cannot be used to establish a lower limit on $E F$.

\section{Box modeling of KORUS-AQ observations}

To complement the analysis shown in Fig. 2 , and to confirm that $R_{\mathrm{obs}} / R_{\mathrm{FF}}<1$ could not be produced by changing chemistry in an evolving plume, we also ran a series of simulations examining the evolution of $\mathrm{NO}_{\mathrm{y}}$ over the Yellow Sea. The effect of enhanced particle-phase $\mathrm{HNO}_{3}$ photolysis was tested by comparing the results from simulation runs with seven different EFs: 1, 7, 10, 30, 50, 100, and 300. In all simulations, particle-phase $\mathrm{HNO}_{3}$ photolysis was assumed to produce $\mathrm{HONO}$ in $100 \%$ yield, with no direct production of $\mathrm{NO}_{\mathrm{x}}$.

Due to significant uncertainties in many of the input parameters, random sampling was used to test the effects of different chemical parameters (Table S2), initial conditions (Table S3), and background concentrations (Table S4). Lacking detailed atmospheric measurements over China, we use as initial conditions the $5 \%$ of points observed during KORUS-AQ with the lowest $2 \mathrm{BN} / \mathrm{nB}$ ratios. A random point from these observations was selected independently for each simulation, and the measured concentrations at that point were used as initial conditions for that run. Similarly, background concentrations were taken as a random sample from observations in the lower free troposphere $(2-4 \mathrm{~km})$ over the Yellow Sea. FLEXPART back trajectories of air in the lower free troposphere show that these airmasses were less likely to be stagnant than in the boundary layer, but typically originated in similar locations (Fig. S4). Gas-particle partitioning of $\mathrm{HNO}_{3}$ was included as a fixed parameter that we varied based on the observations. For each simulation, a random value from the distribution of observed gas-particle partitionings was selected and assumed to remain constant for the model run. For parameters that were not measured (e.g. $\left.\left[\mathrm{Br}_{\mathrm{y}}\right]\right)$, a plausible range of values was constructed with the same best-guess estimate as used in the calculation of $R_{\mathrm{FF}}$, and a random value from within that distribution was chosen independently for each simulation 
run.

100 different simulations were run for each $E F$, and each simulation was run for five days. To ensure that the comparison of model results to observations is not biased by different airmasses ages, only a portion of each model simulation was included. To match the distribution of modeled and observed airmass ages, a random sample of $1002 \mathrm{BN} / \mathrm{nB}$ ratios was generated that matched the observed distribution of $2 \mathrm{BN} / \mathrm{nB}$ over the Yellow Sea; then, for each of the model runs, only the timesteps with the modeled $2 \mathrm{BN} / \mathrm{nB}$ ratios that most closely matched the random sample were selected. The sub-sampling procedure has only a minor effect on the results. Comparison of the observed distribution of $2 \mathrm{BN} / \mathrm{nB}$ ratios with those calculated by the model in the first three days after initialization show reasonably good agreement, although model runs using the highest $E F$ s result in air that is more aged than typically observed (Fig. S6). The sub-sample of each model run was further limited to daylight hours (solar zenith angle $\leq 45^{\circ}$ ), to match the conditions when the DC-8 sampled air over the Yellow Sea.

The selected model points from each of the 100 different simulations for each $E F$ were aggregated, and then compared with $R_{\text {obs }}$ (Fig. 3a), as well as with concentrations of $\mathrm{NO}_{\mathrm{x}}$, $\mathrm{HNO}_{3}, \Sigma \mathrm{PAN}$, and $\mathrm{OH}$ (Fig. 3b-e). Model results and observations are presented as probability distributions, with the median highlighted as a circle (modeled) or a diamond (observed).

The model runs with the lowest EFs (1-10) are found to most closely reproduce $R_{\text {obs }}$. The overall spread in modeled $R$ is greater than that observed over the Yellow Sea, suggesting that the range of input parameters is broader than that encountered in reality. The model runs with higher EFs (50-300) cannot reproduce values of $R_{\text {obs }}$ of 0.06 or less, and at the highest $E F$ values, many of the model runs predict $R$ values of $0.3-1$, values almost never observed over the Yellow Sea during KORUS-AQ. For a given EF, the spread in modeled $\mathrm{NO}_{x}$ to $\mathrm{HNO}_{3}$ ratios was mostly explained by variation in parameters that controlled either the physical loss of $\mathrm{HNO}_{3}$ or the gross production rate of $\mathrm{HO}_{\mathrm{x}}$ radicals. This includes the 
background concentration and deposition velocity of $\mathrm{HNO}_{3}$, relative humidity, temperature, and background $\mathrm{O}_{3}$ concentration.

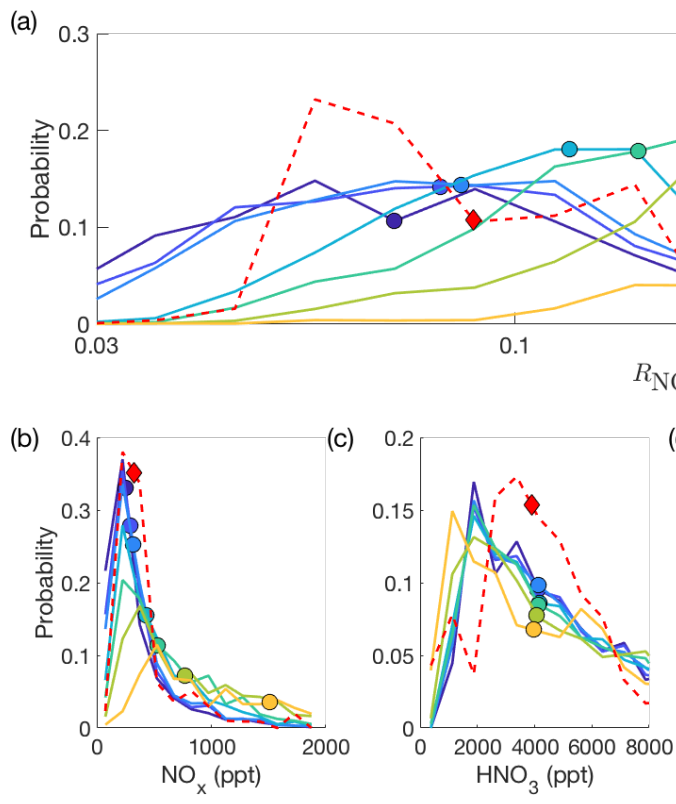

Figure 3: Probability distribution functions of $R_{\mathrm{obs}}, \mathrm{NO}_{\mathrm{x}}, \mathrm{HNO}_{3}, \Sigma \mathrm{PANs}$, and $\mathrm{OH}$ from observations over the Yellow Sea and comparison with box model results using different assumed EFs.

Surprisingly, the increase in modeled $R$ with increasing $E F$ is not due to changes in the concentration of $\mathrm{HNO}_{3}$ but instead is due to changes in $\mathrm{NO}_{\mathrm{x}}$ (Fig. 3b-c). The median concentration of $\mathrm{HNO}_{3}$ shows almost no change with increasing $E F$, indicating that the concentration of $\mathrm{HNO}_{3}$ is controlled in large part by dilution and deposition rather than chemistry. The modeled distribution of $\mathrm{HNO}_{3}$ is broader and peaks at a lower concentration than that observed, perhaps suggesting that the true deposition velocity for gas-phase $\mathrm{HNO}_{3}$ is on the low-end of the range sampled by the model $\left(1-4 \mathrm{~cm} \mathrm{~s}^{-1}\right)$. Wet deposition, not included in the model, also efficiently removes $\mathrm{HNO}_{3}$ from the atmosphere and could potentially explain some of the observations with very low concentrations of $\mathrm{HNO}_{3}$.

The modeled concentration of $\mathrm{NO}_{\mathrm{x}}$ is much more sensitive to $E F$, likely reflecting the dominance of chemical processes to the $\mathrm{NO}_{\mathrm{x}}$ budget. The model most closely reproduces the observed $\mathrm{NO}_{\mathrm{x}}$ distribution at low $E F \mathrm{~s}$, but generally underestimates $\mathrm{NO}_{\mathrm{x}}$ and overestimates 
PAN (Fig. 3b,d). Higher EFs are also associated with greater concentrations of $\mathrm{OH}$, due to increased $\mathrm{HO}_{\mathrm{x}}$ cycling by $\mathrm{NO}$ (Fig. 3e). Production of HONO by nitrate photolysis also leads to production of $\mathrm{HO}_{\mathrm{x}}$ radicals; however, the production of $\mathrm{OH}$ directly due to nitrate photolysis was less than $10 \%$ of $\mathrm{HO}_{\mathrm{x}}$ production from $\mathrm{O}_{3}$ and $\mathrm{HCHO}$ photolysis for all $E F$ s. Based on the results of Fig. 3, the observations over the Yellow Sea can be most accurately reproduced with low $E F \mathrm{~s}$, of 1-30. As the model does not take into account wet deposition or the effects of enhanced aerosol nitrate photolysis on background $\mathrm{HNO}_{3}$ concentrations, an $E F$ of 30 represents a likely upper limit to the true enhancement factor.

\section{Comparison of KORUS-AQ to other measurements}

To examine whether the results from KORUS-AQ are representative, the analysis of $R_{\mathrm{obs}} / R_{\mathrm{FF}}$ was extended to six additional airborne campaigns conducted over the past 15 years on the NASA DC-8. In order to focus the analysis on airmasses where $\mathrm{HNO}_{3}$ loss is most important, we only include observations of highly aged air, which we define as points with $2 \mathrm{BN} / \mathrm{nB}$ greater than 0.06 . The observations were further limited to the lowest $1.3 \mathrm{~km}$ above ground level.

Combined results from all seven campaigns are shown in Fig. 4. The top panel shows the distribution of $R_{\text {obs }}$ found in highly aged air. The bottom panel extends the analysis of Fig. 2 and presents the results for the case where $E F=10$ and using our best-guess assumptions about deposition and heterogeneous chemistry (Table S1). The same box-model calculations used in Fig. 2 were repeated for the six additional campaigns to estimate the concentration of halogen nitrates and $\mathrm{RO}_{2}$ radicals. $R_{\mathrm{FF}}$ for SEAC4RS was calculated using a constant $\mathrm{OH}$ concentration of 0.18 ppt. The criteria used to select highly aged air in this section, chosen to ensure consistency among campaigns, are less restrictive than the ones applied to KORUS-AQ earlier in the paper and cause the values of $R_{\mathrm{obs}}$ and $R_{\mathrm{obs}} / R_{\mathrm{FF}}$ reported in Fig. 4 to be higher than those reported in Fig. 2 .

The results from KORUS-AQ are generally in line with those from other campaigns, al- 

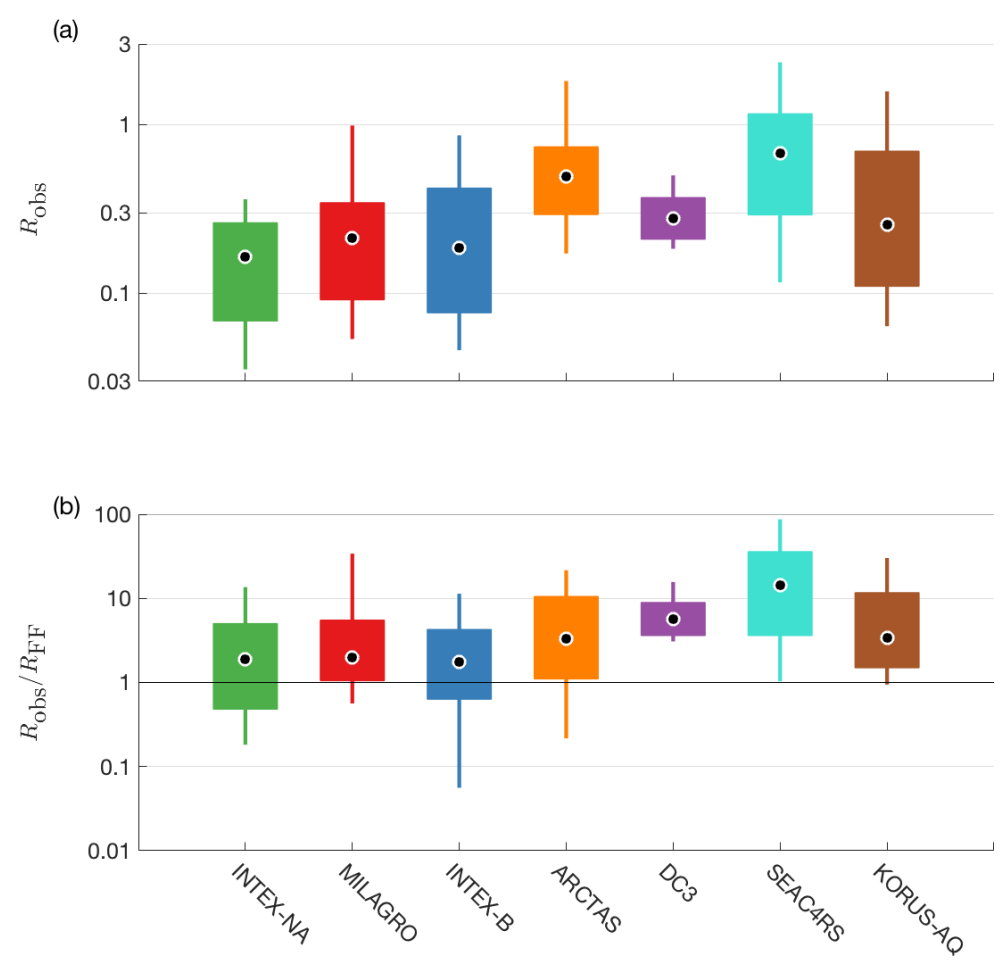

Figure 4: Analysis from KORUS-AQ extended to 6 additional campaign deployments. Panel (a) shows the observed far-field ratios of $\mathrm{NO}_{\mathrm{x}} / \mathrm{HNO}_{3}$; Panel (b) shows the the ratio of ratios $R_{\mathrm{obs}} / R_{\mathrm{FF}}$, calculated assuming $E F=10$ and $v_{\mathrm{dep}, \mathrm{HNO}_{3}}=2 \mathrm{~cm} \mathrm{~s}^{-1}$.

though there is significant variation. One possible explanation for the variability in $R_{\mathrm{obs}} / R_{\mathrm{FF}}$ is that there is variation in the rate of particulate nitrate photolysis between environments. Previous studies of $\mathrm{HNO}_{3}$ photolysis on surfaces and in particles collected on filters have found significant variability in the reported photolysis rates, determined by, among other factors, the total concentration of particulate nitrate, ${ }^{16}$ the presence of mineral dust aerosols, ${ }^{50}$ and relative humidity. ${ }^{50}$ However, observed values of $R_{\text {obs }}$ in highly aged airmasses for all deployments do not show a significant trend with any of these three parameters (Fig. S7). But without direct measurements of the nitrate photolysis rate or HONO concentration, our power to find short periods of enhanced photolysis is limited. 


\section{Implications for $\mathrm{HNO}_{3}$ and $\mathrm{HONO}$}

Based on eigenvector analysis of seven different airborne campaigns and detailed box modeling of plumes over the Yellow Sea, we have shown that observed values of $\mathrm{NO}_{\mathrm{x}}$ and $\mathrm{HNO}_{3}$ are consistent either with no enhanced aerosol nitrate photolysis, or with a relatively moderate enhancement factor. Using our best guess about the deposition velocity of $\mathrm{HNO}_{3}$ and the contribution of unmeasured halogens to $\mathrm{HNO}_{3}$ production, an enhancement factor of up to 10 is consistent with $R_{\text {obs }}$ measured over the Yellow Sea. Using more generous assumptions for these parameters, an enhancement factor of up to 30 is consistent. Because these calculations compare observed $\mathrm{NO}_{\mathrm{x}}$ to $\mathrm{HNO}_{3}$ ratios with those predicted in infinitely aged air and do not take into account wet deposition, the $E F$ s we calculate likely represent an upper limit to the compatible photolysis rate.

(a)
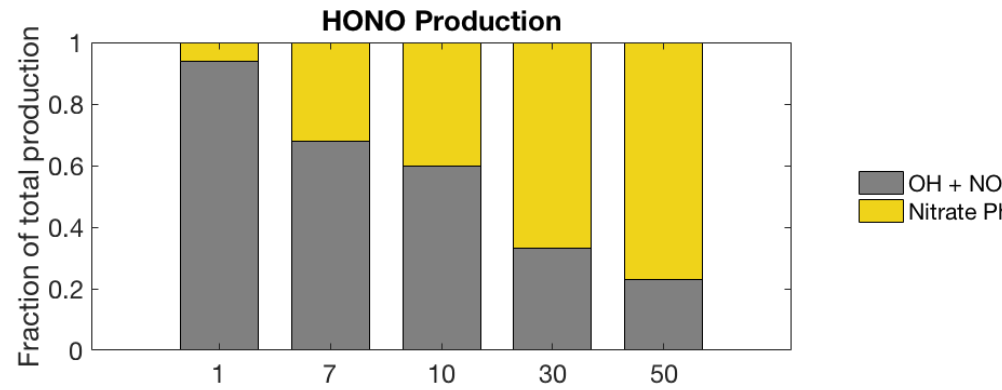

Nitrate Photolysis

(b)

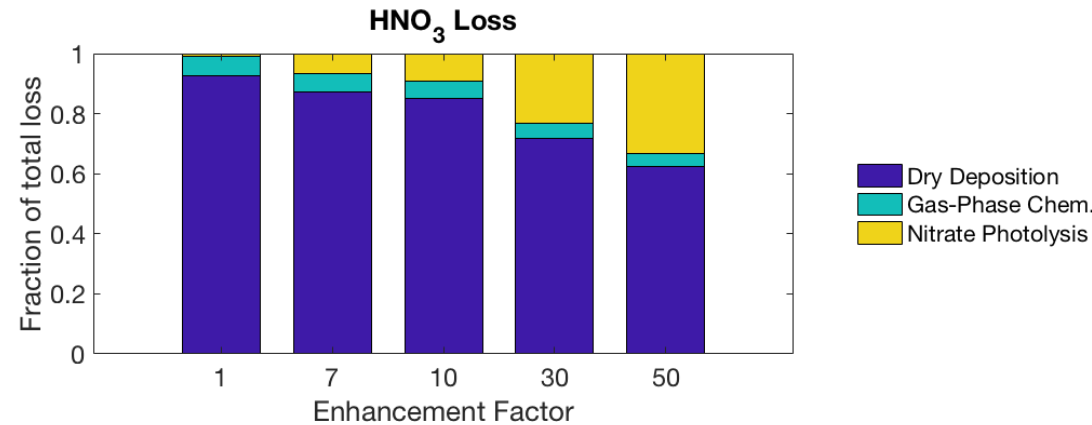

Figure 5: Effect of different particulate nitrate photolysis rates on the production of HONO (Panel a) and the loss of $\mathrm{HNO}_{3}$ (Panel b), shown as a stacked bar graph. Each segment corresponds to the average fraction of total production or loss caused by a single pathway. Chemical rates were calculated using the average of all observations from all seven campaigns in the boundary layer in highly aged air, using the best-guess parameters in Table S1.

By turning aerosol nitrate into a source of $\mathrm{NO}_{\mathrm{x}}$, even relatively moderate $E F$ s could 
help resolve discrepancies between modeled and observed ratios of $\mathrm{NO}_{\mathrm{x}}$ to $\mathrm{HNO}_{3}$ in the remote atmosphere. Figure 5 shows the effect of different assumed $E F$ s on the HONO and $\mathrm{HNO}_{3}$ budgets. At $E F=10$, nitrate photolysis would account for an average of $40 \%$ of total $\mathrm{HONO}$ production, but only $10 \%$ of $\mathrm{HNO}_{3}$ loss, indicating that these rates of nitrate photolysis would have a much larger effect on $\mathrm{HONO}$ than on $\mathrm{HNO}_{3}$.

Our result, arguing in favor of at most moderate enhancements in particle-phase nitrate photolysis, is compatible with multiple previous studies examining the chemistry of both HONO and $\mathrm{NO}_{\mathrm{x}}$. An average $E F$ of 10-30 is less than our upper limit of $E F$ and would be within the range found by Reed et al. ${ }^{10}(E F=10)$ and Kasibhatla et al. ${ }^{12}(E F=25-50)$ to best explain observations of $\mathrm{HONO}$ and $\mathrm{NO}_{\mathrm{x}}$ at the Cape Verde Observatory.

However, there are also several studies that measured significantly higher rates of surfaceand aerosol-phase nitric acid photolysis ${ }^{13,16,21,51}$ as well as studies that postulated much higher rates of nitrate photolysis to explain observations of HONO. ${ }^{11,14,15}$ Reconciling these observations with the present study would require either significant variability in the nitrate photolysis rate or additional sources of HONO. Laboratory studies have shown significant variability in the measured nitrate photolysis rate between samples as well as between populations of nitrate in the same sample. ${ }^{16,51,52}$

Alternatively, our calculation of $R_{\mathrm{FF}}$ could be missing an important oxidant that converts $\mathrm{NO}_{\mathrm{x}}$ into $\mathrm{HNO}_{3}$. Halogen concentrations are poorly constrained by current observations, and it is possible that total halogen concentrations could be much higher than typically assumed. ${ }^{53}$ Halogen concentrations an order of magnitude larger than we assumed in our calculations could increase our maximum compatible $E F$ from 30 up to 50 . It is also possible that unknown oxidants represent a significant missing source of $\mathrm{HNO}_{3}$ in the atmosphere.

Based on our observations of $\mathrm{NO}_{\mathrm{x}}$ and $\mathrm{HNO}_{3}$, we do not find evidence that particlephase $\mathrm{HNO}_{3}$ photolysis is extremely rapid, suggesting that if regional or global modeling studies include this pathway in their mechanisms, they should use an enhancement factor of 30 or less. On a global scale, nitrate photolysis is significantly slower than wet and dry 
deposition, making re-noxification pathways at most a minor $\mathrm{HNO}_{3}$ loss process. While enhancements of particle nitrate photolysis could help explain observations of HONO in the remote troposphere, the effects of nitrate photolysis on ozone and $\mathrm{NO}_{\mathrm{x}}$ are likely to be smaller than proposed in some recent studies.

\section{Acknowledgement}

The authors thank NASA for support via NNX15AT85G (Berkeley), NNX15AT97G and NNX14AP46G (Caltech), NNX14AP46G (UNH) and NNX16AD96G (to Christoph Knote). Michelle J. Kim was supported by NSF AGS award 1524860. Methanol and acetaldehyde measurements were supported by the Austrian Federal Ministry for Transport, Innovation and Technology (bmvit) through the Austrian Research Promotion Agency (FFG). The authors thank Alan Fried for the formaldehyde measurements, Armin Wisthaler for the methanol and acetaldehyde measurements, Christoph Knote for the FLEXPART model results, Glenn Diskin for the $\mathrm{CH}_{4}$ and CO measurements, and Andrew Weinheimer and Denise Montzka for NO measurements. We thank Tamara Sparks and Alex Teng for assistance in the field, the ground and flight crew of the DC-8, and the KORUS-AQ science team.

\section{Supporting Information Available}

The following files are available free of charge.

- Nitrate_Photolysis_Supporting_Information.pdf: Figures showing flight tracks, inorganic particle composition, FLEXPART back trajectories, evolution of $R_{\mathrm{FF}}$ with airmass age, modeled airmass age, and trends in $R_{\text {obs }}$; Tables listing all the parameters used in calculations of $R_{\mathrm{FF}}$ and in plume model; Equations with explicit formulas for effective rate constants used in the eigenvector analysis. 


\section{References}

(1) Stavrakou, T.; Müller, J.-F.; Boersma, K. F.; van der A, R. J.; Kurokawa, J.; Ohara, T.; Zhang, Q. Key chemical $\mathrm{NO}_{\mathrm{x}}$ sink uncertainties and how they influence top-down emissions of nitrogen oxides. Atmos. Chem. Phys. 2013, 13, 9057-9082, DOI: 10.5194/acp-13-9057-2013.

(2) Dulitz, K.; Amedro, D.; Dillon, T. J.; Pozzer, A.; Crowley, J. N. Temperature(208-318 K) and pressure-(18-696 Torr) dependent rate coefficients for the reaction between $\mathrm{OH}$ and $\mathrm{HNO}_{3}$. Atmos. Chem. Phys. 2018, 18, 2381-2394, DOI: 10.5194/acp-18-2381-2018.

(3) Pusede, S. E.; Duffey, K. C.; Shusterman, A. A.; Saleh, A.; Laughner, J. L.; Wooldridge, P. J.; Zhang, Q.; Parworth, C. L.; Kim, H.; Capps, S. L.; Valin, L. C.; Cappa, C. D.; Fried, A.; Walega, J.; Nowak, J. B.; Weinheimer, A. J.; Hoff, R. M.; Berkoff, T. A.; Beyersdorf, A. J.; Olson, J.; Crawford, J. H.; Cohen, R. C. On the effectiveness of nitrogen oxide reductions as a control over ammonium nitrate aerosol. Atmos. Chem. Phys. 2016, 16, 2575-2596, DOI: 10.5194/acp-16-2575-2016.

(4) Bertram, T. H.; Perring, A. E.; Wooldridge, P. J.; Crounse, J. D.; Kwan, A. J.; Wennberg, P. O.; Scheuer, E.; Dibb, J.; Avery, M.; Sachse, G.; Vay, S. A.; Crawford, J. H.; McNaughton, C. S.; Clarke, A.; Pickering, K. E.; Fuelberg, H.; Huey, G.; Blake, D. R.; Singh, H. B.; Hall, S. R.; Shetter, R. E.; Fried, A.; Heikes, B. G.; Cohen, R. C. Direct Measurements of the Convective Recycling of the Upper Troposphere. Science 2007, 315, 816-820, DOI: 10.1126/science.1134548.

(5) Neuman, J. A.; Parrish, D. D.; Trainer, M.; Ryerson, T. B.; Holloway, J. S.; Nowak, J. B.; Swanson, A.; Flocke, F.; Roberts, J. M.; Brown, S. S.; Stark, H.; Sommariva, R.; Stohl, A.; Peltier, R.; Weber, R.; Wollny, A. G.; Sueper, D. T.; Hubler, G.; Fehsenfeld, F. C. Reactive nitrogen transport and photochemistry in urban plumes 
over the North Atlantic Ocean. J. Geophys. Res. Atmos. 2006, 111, D23S54, DOI: 10.1029/2005JD007010.

(6) Hauglustaine, D. A.; Ridley, B. A.; Solomon, S.; Hess, P. G.; Madronich, S. $\mathrm{HNO}_{3} / \mathrm{NO}_{x}$ ratio in the remote troposphere During MLOPEX 2: Evidence for nitric acid reduction on carbonaceous aerosols? Geophys. Res. Lett. 1996, 23, 2609-2612, DOI: 10.1029/96GL02474.

(7) Gao, R. S.; Fahey, D. W.; Del Negro, L. A.; Donnelly, S. G.; Keim, E. R.; Neuman, J. A.; Teverovskaia, E.; Wennberg, P. O.; Hanisco, T. F.; Lanzendorf, E. J.; Proffitt, M. H.; Margitan, J. J.; Wilson, J. C.; Elkins, J. W.; Stimpfle, R. M.; Cohen, R. C.; McElroy, C. T.; Bui, T. P.; Salawitch, R. J.; Brown, S. S.; Ravishankara, A. R.; Portmann, R. W.; Ko, M. K. W.; Weisenstein, D. K.; Newman, P. A. A comparison of observations and model simulations of $\mathrm{NO}_{\mathrm{x}} / \mathrm{NO}_{\mathrm{y}}$ in the lower stratosphere. Geophys. Res. Lett. 1999, 26, 1153-1156, DOI: 10.1029/1999GL900162.

(8) Perkins, K. K.; Hanisco, T. F.; Cohen, R. C.; Koch, L. C.; Stimpfle, R. M.; Voss, P. B.; Bonne, G. P.; Lanzendorf, E. J.; Anderson, J. G.; Wennberg, P. O.; Gao, R. S.; Del Negro, L. A.; Salawitch, R. J.; McElroy, C. T.; Hintsa, E. J.; Loewenstein, M.; Bui, T. P. The $\mathrm{NO}_{x}-\mathrm{HNO}_{3}$ System in the Lower Stratosphere: Insights from In Situ Measure-

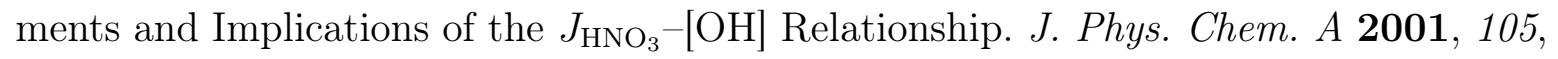
1521-1534, DOI: 10.1021/jp002519n.

(9) Chatfield, R. B. Anomalous $\mathrm{HNO}_{3} / \mathrm{NO}_{x}$ ratio of remote tropospheric air: Conversion of nitric acid to formic acid and $\mathrm{NO}_{x}$ ? Geophys. Res. Lett. 1994, 21, 2705-2708, DOI: 10.1029/94GL02659.

(10) Reed, C.; Evans, M. J.; Crilley, L. R.; Bloss, W. J.; Sherwen, T.; Read, K. A.; Lee, J. D.; Carpenter, L. J. Evidence for renoxification in the tropical marine boundary layer. Atmos. Chem. Phys. 2017, 17, 4081-4092, DOI: 10.5194/acp-17-4081-2017. 
(11) Ye, C.; Heard, D. E.; Whalley, L. K. Evaluation of Novel Routes for $\mathrm{NO}_{x}$ Formation in Remote Regions. Environ. Sci. Technol. 2017, 51, 7442-7449, DOI: 10.1021/acs.est. $6 \mathrm{~b} 06441$.

(12) Kasibhatla, P.; Sherwen, T.; Evans, M. J.; Carpenter, L. J.; Reed, C.; Alexander, B.; Chen, Q.; Sulprizio, M. P.; Lee, J. D.; Read, K. A.; Bloss, W.; Crilley, L. R.; Keene, W. C.; Pszenny, A. A. P.; Hodzic, A. Global impact of nitrate photolysis in sea-salt aerosol on $\mathrm{NO}_{\mathrm{x}}, \mathrm{OH}$, and $\mathrm{O}_{3}$ in the marine boundary layer. Atmos. Chem. Phys. 2018, 18, 11185-11203, DOI: https://doi.org/10.5194/acp-18-11185-2018.

(13) Zhou, X.; Gao, H.; He, Y.; Huang, G.; Bertman, S. B.; Civerolo, K.; Schwab, J. Nitric acid photolysis on surfaces in low- $\mathrm{NO}_{\mathrm{x}}$ environments: Significant atmospheric implications. Geophys. Res. Lett. 2003, 30, 2217, DOI: 10.1029/2003GL018620.

(14) Zhou, X.; Zhang, N.; TerAvest, M.; Tang, D.; Hou, J.; Bertman, S.; Alaghmand, M.; Shepson, P. B.; Carroll, M. A.; Griffith, S.; Dusanter, S.; Stevens, P. S. Nitric acid photolysis on forest canopy surface as a source for tropospheric nitrous acid. Nat. Geosci. 2011, 4, 440-443, DOI: $10.1038 /$ ngeo1164.

(15) Ye, C.; Zhou, X.; Pu, D.; Stutz, J.; Festa, J.; Spolaor, M.; Tsai, C.; Cantrell, C.; Mauldin, R. L.; Campos, T.; Weinheimer, A.; Hornbrook, R. S.; Apel, E. C.; Guenther, A.; Kaser, L.; Yuan, B.; Karl, T.; Haggerty, J.; Hall, S.; Ullmann, K.; Smith, J. N.; Ortega, J.; Knote, C. Rapid cycling of reactive nitrogen in the marine boundary layer. Nature 2016, 532, 489-491, DOI: 10.1038/nature17195.

(16) Ye, C.; Zhang, N.; Gao, H.; Zhou, X. Photolysis of Particulate Nitrate as a Source of HONO and $\mathrm{NO}_{x}$. Environ. Sci. Technol. 2017, 51, 6849-6856, DOI: 10.1021/acs.est. $7 \mathrm{~b} 00387$.

(17) Svoboda, O.; Kubelová, L.; Slavíček, P. Enabling Forbidden Processes: Quantum and 
Solvation Enhancement of Nitrate Anion UV Absorption. J. Phys. Chem. A 2013, 117, 12868-12877, DOI: 10.1021/jp4098777.

(18) Warneck, P.; Wurzinger, C. Product quantum yields for the 305-nm photodecomposition of nitrate in aqueous solution. J. Phys. Chem. 1988, 92, 6278-6283, DOI: $10.1021 / \mathrm{j} 100333 \mathrm{a} 022$.

(19) Nissenson, P.; Dabdub, D.; Das, R.; Maurino, V.; Minero, C.; Vione, D. Evidence of the water-cage effect on the photolysis of $\mathrm{NO}_{3}{ }^{-}$and $\mathrm{FeOH}^{2+}$. Implications of this effect and of $\mathrm{H}_{2} \mathrm{O}_{2}$ surface accumulation on photochemistry at the airwater interface of atmospheric droplets. Atmos. Environ. 2010, 44, 4859-4866, DOI: $10.1016 / j$.atmosenv. 2010.08.035.

(20) Zhu, C.; Xiang, B.; Zhu, L.; Cole, R. Determination of absorption cross sections of surface-adsorbed $\mathrm{HNO}_{3}$ in the 290-330 nm region by Brewster angle cavity ring-down spectroscopy. Chem. Phys. Lett. 2008, 458, 373-377, DOI: $10.1016 /$ j.cplett .2008 .04 .125 .

(21) Zhu, C.; Xiang, B.; Chu, L. T.; Zhu, L. 308 nm Photolysis of Nitric Acid in the Gas Phase, on Aluminum Surfaces, and on Ice Films. J. Phys. Chem. A 2010, 114, 25612568, DOI: 10.1021/jp909867a.

(22) Mao, J.; Ren, X.; Zhang, L.; Van Duin, D. M.; Cohen, R. C.; Park, J.-H.; Goldstein, A. H.; Paulot, F.; Beaver, M. R.; Crounse, J. D.; Wennberg, P. O.; DiGangi, J. P.; Henry, S. B.; Keutsch, F. N.; Park, C.; Schade, G. W.; Wolfe, G. M.; Thornton, J. A.; Brune, W. H. Insights into hydroxyl measurements and atmospheric oxidation in a California forest. Atmos. Chem. Phys. 2012, 12, 8009-8020, DOI: $10.5194 /$ acp-12-8009-2012.

(23) Ryerson, T. B.; Williams, E. J.; Fehsenfeld, F. C. An efficient photolysis system for 
fast-response $\mathrm{NO}_{2}$ measurements. J. Geophys. Res. 2000, 105, 26447-26461, DOI: $10.1029 / 2000 J D 900389$.

(24) Day, D. A.; Wooldridge, P. J.; Dillon, M. B.; Thornton, J. A.; Cohen, R. C. A thermal dissociation laser-induced fluorescence instrument for in situ detection of $\mathrm{NO}_{2}$, peroxy nitrates, alkyl nitrates, and $\mathrm{HNO}_{3}$. J. Geophys. Res. 2002, 10\%, 4046, DOI: $10.1029 / 2001$ JD000779.

(25) Walega, J. G.; Dye, J. E.; Grahek, F. E.; Ridley, B. K. Compact measurement system for the simultaneous determination of $\mathrm{NO}, \mathrm{NO}_{2}, \mathrm{NOy}$, and $\mathrm{O}_{3}$ using a small aircraft. Proc. SPIE 1433, Measurement of Atmospheric Gases. 1991; pp 232-241, DOI: $10.1117 / 12.46167$

(26) Crounse, J. D.; McKinney, K. A.; Kwan, A. J.; Wennberg, P. O. Measurement of GasPhase Hydroperoxides by Chemical Ionization Mass Spectrometry. Anal. Chem. 2006, 78, 6726-6732, DOI: 10.1021/ac0604235.

(27) Dibb, J. E.; Talbot, R. W.; Scheuer, E. M.; Blake, D. R.; Blake, N. J.; Gregory, G. L.; Sachse, G. W.; Thornton, D. C. Aerosol chemical composition and distribution during the Pacific Exploratory Mission (PEM) Tropics. J. Geosphys. Res. 1999, 104, 57855800, DOI: $10.1029 / 1998 J D 100001$.

(28) Faloona, I. C.; Tan, D.; Lesher, R. L.; Hazen, N. L.; Frame, C. L.; Simpas, J. B.; Harder, H.; Martinez, M.; Di Carlo, P.; Ren, X.; Brune, W. H. A Laser-induced Fluorescence Instrument for Detecting Tropospheric $\mathrm{OH}$ and $\mathrm{HO}_{2}$ : Characteristics and Calibration. J. Atmos. Chem. 2004, 47, 139-167, DOI: 10.1023/B: JOCH. 0000021036.53185 .0 e.

(29) Blake, N. J.; Blake, D. R.; Simpson, I. J.; Meinardi, S.; Swanson, A. L.; Lopez, J. P.; Katzenstein, A. S.; Barletta, B.; Shirai, T.; Atlas, E.; Sachse, G.; Avery, M.; Vay, S.; Fuelberg, H. E.; Kiley, C. M.; Kita, K.; Rowland, F. S. NMHCs and halocarbons in 
Asian continental outflow during the Transport and Chemical Evolution over the Pacific (TRACE-P) Field Campaign: Comparison With PEM-West B. J. Geophys. Res. 2003, 108, 8806, DOI: 10.1029/2002JD003367.

(30) Wisthaler, A.; Hansel, A.; Dickerson, R. R.; Crutzen, P. J. Organic trace gas measurements by PTR-MS during INDOEX 1999. J. Geophys. Res. Atmos. 2002, 10\%, 8024, DOI: $10.1029 / 2001$ JD000576.

(31) Richter, D.; Weibring, P.; Walega, J. G.; Fried, A.; Spuler, S. M.; Taubman, M. S. Compact highly sensitive multi-species airborne mid-IR spectrometer. Appl. Phys. B 2015, 119, 119-131, DOI: 10.1007/s00340-015-6038-8.

(32) Sachse, G. W.; Hill, G. F.; Wade, L. O.; Perry, M. G. Fast-response, high-precision carbon monoxide sensor using a tunable diode laser absorption technique. J. Geophys. Res. Atmos. 1987, 92, 2071-2081, DOI: 10.1029/JD092iD02p02071.

(33) Shetter, R. E.; Müller, M. Photolysis frequency measurements using actinic flux spectroradiometry during the PEM-Tropics mission: Instrumentation description and some results. J. Geophys. Res. Atmos. 1999, 104, 5647-5661, DOI: 10.1029/98JD01381.

(34) Bertman, S. B.; Roberts, J. M.; Parrish, D. D.; Buhr, M. P.; Goldan, P. D.; Kuster, W. C.; Fehsenfeld, F. C.; Montzka, S. A.; Westberg, H. Evolution of alkyl nitrates with air mass age. J. Geophys. Res. 1995, 100, 22805-22813, DOI: 10.1029/95JD02030.

(35) Perring, A. E.; Bertram, T. H.; Farmer, D. K.; Wooldridge, P. J.; Dibb, J.; Blake, N. J.; Blake, D. R.; Singh, H. B.; Fuelberg, H.; Diskin, G.; Sachse, G.; Cohen, R. C. The production and persistence of $\Sigma \mathrm{RONO}_{2}$ in the Mexico City plume. Atmos. Chem. Phys. 2010, 10, 7215-7229, DOI: 10.5194/acp-10-7215-2010.

(36) Clemitshaw, K. C.; Williams, J.; Rattigan, O. V.; Shallcross, D. E.; Law, K. S.; Cox, R. A. Gas-phase ultraviolet absorption cross-sections and atmospheric lifetimes 
of several $\mathrm{C}_{2}-\mathrm{C}_{5}$ alkyl nitrates. J. Photochem. Photobio. A 1997, 102, 117-126, DOI: $10.1016 / \mathrm{S} 1010-6030$ (96) 04458-9.

(37) Wolfe, G. M.; Marvin, M. R.; Roberts, S. J.; Travis, K. R.; Liao, J. The Framework for 0-D Atmospheric Modeling (F0AM) v3.1. Geosci. Model Dev. 2016, 9, 3309-3319, DOI: $10.5194 /$ gmd-9-3309-2016.

(38) Jenkin, M. E.; Young, J. C.; Rickard, A. R. The MCM v3.3.1 degradation scheme for isoprene. Atmos. Chem. Phys. 2015, 15, 11433-11459, DOI: $10.5194 /$ acp-15-11433-2015.

(39) Sherwen, T.; Schmidt, J. A.; Evans, M. J.; Carpenter, L. J.; Großmann, K.; Eastham, S. D.; Jacob, D. J.; Dix, B.; Koenig, T. K.; Sinreich, R.; Ortega, I.; Volkamer, R.; Saiz-Lopez, A.; Prados-Roman, C.; Mahajan, A. S.; Ordóñez, C. Global impacts of tropospheric halogens $(\mathrm{Cl}, \mathrm{Br}, \mathrm{I})$ on oxidants and composition in GEOS-Chem. Atmos. Chem. Phys. 2016, 16, 12239-12271, DOI: 10.5194/acp-16-12239-2016.

(40) Fisher, J. A.; Jacob, D. J.; Travis, K. R.; Kim, P. S.; Marais, E. A.; Chan Miller, C.; Yu, K.; Zhu, L.; Yantosca, R. M.; Sulprizio, M. P.; Mao, J.; Wennberg, P. O.; Crounse, J. D.; Teng, A. P.; Nguyen, T. B.; St. Clair, J. M.; Cohen, R. C.; Romer, P.; Nault, B. A.; Wooldridge, P. J.; Jimenez, J. L.; Campuzano-Jost, P.; Day, D. A.; Hu, W.; Shepson, P. B.; Xiong, F.; Blake, D. R.; Goldstein, A. H.; Misztal, P. K.; Hanisco, T. F.; Wolfe, G. M.; Ryerson, T. B.; Wisthaler, A.; Mikoviny, T. Organic nitrate chemistry and its implications for nitrogen budgets in an isoprene- and monoterpene-rich atmosphere: constraints from aircraft $\left(\mathrm{SEAC}^{4} \mathrm{RS}\right)$ and ground-based (SOAS) observations in the Southeast US. Atmos. Chem. Phys. 2016, 16, 5969-5991, DOI: $10.5194 /$ acp-16-5969-2016.

(41) Deiber, G.; George, Ch.; Le Calvé, S.; Schweitzer, F.; Mirabel, Ph. Uptake study of 
$\mathrm{ClONO}_{2}$ and $\mathrm{BrONO}_{2}$ by Halide containing droplets. Atmos. Chem. Phys. 2004, 4, 1291-1299, DOI: $10.5194 /$ acp-4-1291-2004.

(42) Hanson, D. R.; Ravishankara, A. R.; Lovejoy, E. R. Reaction of $\mathrm{BrONO}_{2}$ with $\mathrm{H}_{2} \mathrm{O}$ on submicron sulfuric acid aerosol and the implications for the lower stratosphere. $J$. Geophys. Res. 1996, 101, 9063-9069, DOI: 10.1029/96JD00347.

(43) McDuffie, E. E.; Fibiger, D. L.; Dubé, W. P.; Lopez-Hilfiker, F.; Lee, B. H.; Thornton, J. A.; Shah, V.; Jaeglé, L.; Guo, H.; Weber, R. J.; Reeves, J. M.; Weinheimer, A. J.; Schroder, J. C.; Campuzano-Jost, P.; Jimenez, J. L.; Dibb, J. E.; Veres, P.; Ebben, C.; Sparks, T. L.; Wooldridge, P. J.; Cohen, R. C.; Hornbrook, R. S.; Apel, E. C.; Campos, T.; Hall, S. R.; Ullmann, K.; Brown, S. S. Heterogeneous $\mathrm{N}_{2} \mathrm{O}_{5}$ Uptake During Winter: Aircraft Measurements During the 2015 WINTER Campaign and Critical Evaluation of Current Parameterizations. J. Geophys. Res. Atmos. 2018, 123, 4345-4372, DOI: $10.1002 / 2018 J D 028336$.

(44) Ganzeveld, L.; Lelieveld, J. Dry deposition parameterization in a chemistry general circulation model and its influence on the distribution of reactive trace gases. J. Geophys. Res. 1995, 100, 20999-21012, DOI: 10.1029/95JD02266.

(45) Horii, C. V.; William Munger, J.; Wofsy, S. C.; Zahniser, M.; Nelson, D.; Barry McManus, J. Atmospheric reactive nitrogen concentration and flux budgets at a Northeastern U.S. forest site. Agr. Forest Meteorol. 2006, 136, 159-174, DOI: $10.1016 / j$. agrformet .2006 .03 .005 .

(46) Nguyen, T. B.; Crounse, J. D.; Teng, A. P.; St. Clair, J. M.; Paulot, F.; Wolfe, G. M.; Wennberg, P. O. Rapid deposition of oxidized biogenic compounds to a temperate forest. Proc. Natl. Acad. Sci. USA 2015, 112, E392-E401, DOI: 10.1073/pnas.1418702112.

(47) Stohl, A.; Forster, C.; Frank, A.; Seibert, P.; Wotawa, G. Technical note: The La- 
grangian particle dispersion model FLEXPART version 6.2. Atmos. Chem. Phys. 2005, 5, 2461-2474, DOI: 10.5194/acp-5-2461-2005.

(48) Pérez, I. M.; LaFranchi, B. W.; Cohen, R. C. Nitrogen oxide chemistry in an urban plume: investigation of the chemistry of peroxy and multifunctional organic nitrates with a Lagrangian model. Atmos. Chem. Phys. Discuss. 2009, 9, 27099-27165, DOI: 10.5194/acpd-9-27099-2009.

(49) Nault, B. A.; Garland, C.; Wooldridge, P. J.; Brune, W. H.; Campuzano-Jost, P.; Crounse, J. D.; Day, D. A.; Dibb, J.; Hall, S. R.; Huey, L. G.; Jimenez, J. L.; Liu, X.; Mao, J.; Mikoviny, T.; Peischl, J.; Pollack, I. B.; Ren, X.; Ryerson, T. B.; Scheuer, E.; Ullmann, K.; Wennberg, P. O.; Wisthaler, A.; Zhang, L.; Cohen, R. C. Observational Constraints on the Oxidation of $\mathrm{NO}_{x}$ in the Upper Troposphere. J. Phys. Chem. A 2016, 120, 1468-1478, DOI: 10.1021/acs.jpca.5b07824.

(50) Ndour, M.; Conchon, P.; D’Anna, B.; Ka, O.; George, C. Photochemistry of mineral dust surface as a potential atmospheric renoxification process. Geophys. Res. Lett. 2009, 36, L05816, DOI: 10.1029/2008GL036662.

(51) Baergen, A. M.; Donaldson, D. J. Photochemical Renoxification of Nitric Acid on Real Urban Grime. Environ. Sci. Technol. 2013, 47, 815-820, DOI: 10.1021/es3037862.

(52) Meusinger, C.; Berhanu, T. A.; Erbland, J.; Savarino, J.; Johnson, M. S. Laboratory study of nitrate photolysis in Antarctic snow. I. Observed quantum yield, domain of photolysis, and secondary chemistry. J. Chem. Phys. 2014, 140, 244305, DOI: $10.1063 / 1.4882898$.

(53) Mahajan, A. S.; Oetjen, H.; Lee, J. D.; Saiz-Lopez, A.; McFiggans, G. B.; Plane, J. M. C. High bromine oxide concentrations in the semi-polluted boundary layer. Atmos. Environ. 2009, 43, 3811-3818, DOI: 10.1016/j .atmosenv.2009.05.033. 
${ }_{600}$ Graphical TOC Entry

601

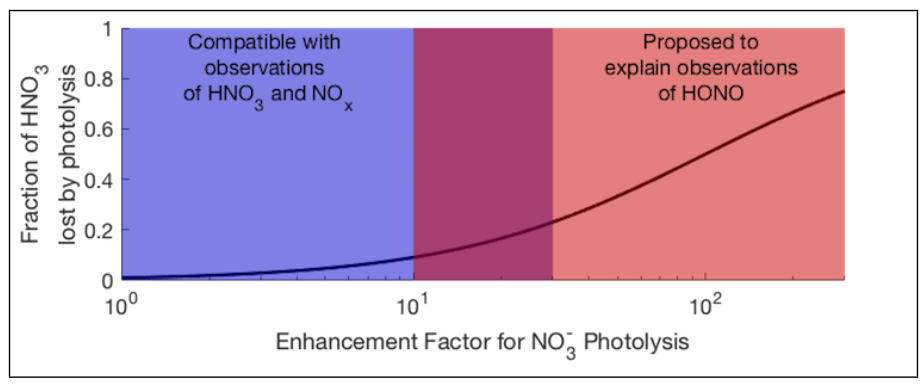

